and biochemical abnormalities. It is suggested that research into the large and important group of "non-serious" head injuries has been neglected, to the detriment of their management.

Figs. 1, 2, and 3 are reproduced by kind permission of $\mathrm{Dr}$. N. C. Nevin.

\section{REFERENCES}

Becker, R. F., Groat, R. A., and Windle, W. F. (1946). Fed. Proc., 5, 7. Biggart, J. H. (1936). Pathology of the Nervous System. Edinburgh. Breig, A. (1960). Biomechanics of the Central Nervous System. Stock-

Brock, S. (1960). Injuries of the Brain and Spinal Cord and Their Coverings, 4th ed. New York.

Caveness, W. F. (1966). In Head Injury Conference Proceedings, edited by W. F. Caveness and A. E. Walker, p. 209. Philadelphia.

Denny-Brown, D., and Russell, W. R. (1941). Brain, 64, 93.

Durand Wever, A M (1929). Münch med Wschr $76,1879$.

Erichsen, J. E. (1866). On Concussion of the Spine, Nervous Shock, and Other Obscure Injuries of the Nervous System. New York

Friede, R. L. (1961). Arch. Neurol. (Chic.), 4, 449

Friedman, A. P., Brenner, C., and Denny-Brown, D. (1945). F. Neurosurg. (Chic.), 2,36

Goldstein, K. (1942). After Effects of Brain Injuries in War, p. 220 London.

Groat, R. A., and Simmons, J. Q. (1950). F. Neuropath. exp. Neurol., 9, 150 .
Haxhe, J. J. (1963). Blood C.S.F. barrier breakdown. Personal communication.

Hilton, J. (1863). Lectures on Rest and Pain. London.

Houdart, R., Cathala, F., Pialoux, P., Raby, D., Fontelle, P., and Vollmer, D. (1966). Presse méd., 74, 449.

Ishii, S. (1966). In Head Injury Conference Proceedings, edited by W. F. Caveness and A. E. Walker, p. 276. Philadelphia.

Kurze, T., Tranquada, R. E., and Benedict, K. (1966). Ibid., p. 254. Philadelphia.

Lishman, W. A. (1966). Proc. roy. Soc. Med., 59, 261.

Mayer, E. (1929). Münch. med. W schr., 76, 2135.

Miller, H. (1961). Brit. med. F., 1, 919.

- (1966). Proc. roy. Soc. Med., 59, 257.

Nevin, N. C. (1964). "Pathology in Cerebral Concussion." Thesis, The Queen's University of Belfast

Pott, P. (1808). The Chirurgical Works. London.

Regler, J. (1879). Uber die Folgen der Verletzung auf Eisenbahnen. Berlin.

Russell, W. R. (1933-4). Trans. med.-chir. Soc. (Edinb.), 129.

and Smith, A. (1961). Arch. Neurol. (Chic.), 5, 4.

Strauss, I., and Savitsky, N. (1934). Arch. Neurol. Psychiat. (Chic.), 31 893.

Strich, S. J. (1961). Lancet, 2, 443.

Strümpeli, A. (1888). Uber die traumatischen Neurosen. Berlin.

Symonds, C. (1962). Lancet, 1, 1.

Symonds, C. (1962). Lancet, 1, 1. Ibid. 1, 7

Taylor, A. R. and Bell, T. K. (1966). Ibid., 2, 178.

Van Harreveld, A (1966). Brain Tissue Electrolytes. Washington, D.C. Wilmot, T. J. (1966). F. Laryng., 80, 1156.

Windle, W. F., Groat, R. A., and Fox, C. A. (1944). Surg. Gynec. Obstet., 79, 561.

Zangwill, O. L. (1966). Proc. roy. Soc. Med., 59, 266.

Zetterholm, S. (1947). Acta psychiat. scand., Suppl. No. 45.

\title{
Prolapse of the Posterior Leaflet of the Mitral Valve: A Clinical, Familial, and Cineangiographic Study
}

\author{
MARY STANNARD,* M.B., B.S. ; J. G. SLOMAN, † M.B., B.SC., M.R.C.P., M.R.C.P.ED., M.R.A.C.P. \\ W. S. C. HARE, $\ddagger$ M.D., M.R.A.C.P., F.F.R., F.C.R.A. ; A. J. GOBLE,§ M.D., M.R.C.P., F.R.A.C.P.
}

Brit. med. F., 1967, 3, 71-74

Mid and late systolic clicks and late systolic murmurs have in the past been regarded as "innocent," and were thought to be due to pericardial adhesions (Wells, 1957 ; McKusick, 1958 ; Ongley et al., 1960 ; Segal and Likoff, 1964). Recently there has been evidence to show that these auscultatory findings are due to an abnormality of the mitral valve and sometimes are associated with a history of anterior chest pain and an abnormal electrocardiogram (Barlow et al., 1963 ; Barlow, 1965 ; Tavel et al., 1965 ; Barlow and Bosman, 1966 ; Criley et al., 1966 ; Leon et al., 1966 ; Linhart and Taylor, 1966). The purpose of this paper is to present our findings in 13 patients with mid or late systolic clicks and late systolic murmurs, with particular reference to the familial nature of this entity and the findings on left ventricular cineangiography and selective coronary arteriography.

\section{Methods and Materials}

Of the 13 patients studied six were referred with anterior chest pain, four because a murmur had been detected on routine examination, and three were siblings of patients already known to us. All were assessed clinically, and an electrocardiogram and a phonocardiogram were made. In six cases haemodynamic studies and left ventricular cineangiography were carried out.

\footnotetext{
* Research Assistant, Cardiac Department, Royal Melbourne Hospital Grant in Aid No. G.428, National Heart Foundation of Australia. † Director, Cardiac Laboratory, Royal Melbourne Hospital. † Professor of Radiology, University of Melbourne. Cardiologist, Royal Melbourne Hospital.
}

Selective coronary arteriography was performed in two patients who presented with severe anterior chest pain.

\section{Findings}

The clinical features are set out in Table I. There was a definite female preponderance in the series, 11 patients being female and two male. Their ages ranged from 28 to 67, with a mean of 46 years.

Chest pain was a significant symptom in six patients. The pain occurred anteriorly in the chest, was stabbing in quality, and. was not related to exertion. In two cases it was severe enough to require analgesics by injection, but most patients had been regarded as suffering from "cardiac neurosis." In no case was there a past history of rheumatic fever or a history of an illness which in retrospect could have been pericarditis. One patient had been involved in a motor-car accident shortly before the murmur was detected, but she could recall no chest injury. Two patients had thyrotoxicosis ; one had symptoms of this at the time her murmur was detected and the other developed it subsequently. One patient had been thought to have had a myocardial infarct some years previously, but there was no evidence of this on her electrocardiogram.

The family history was of significance in only one patient whose father and four brothers were said to have coronary artery disease. However, because a familial incidence of this entity had been suggested, we examined the siblings of our 
TABLE I.-Clinical Features, Electrocardiogram, and Left Ventricular Angiogram in 13 Patients with Mid or Late Systolic Clicks and Late Systolic Murmurs

\begin{tabular}{|c|c|c|c|c|c|c|c|c|}
\hline $\begin{array}{l}\text { Case } \\
\text { No. }\end{array}$ & Sex & Age & Symptoms & Past History & Familial & $\begin{array}{l}\text { Auscultation and } \\
\text { Phonocardiogram }\end{array}$ & Electrocardiogram & Angiogram \\
\hline 1 & $\mathbf{F}$ & 42 & $\begin{array}{l}\text { Nocturnal dyspnoea. } \\
\text { Thyrotoxicosis }\end{array}$ & Car accident & + & $\begin{array}{l}\text { Late click. Late systolic } \\
\text { murmur }\end{array}$ & $\begin{array}{l}\text { V.B.S. L.V.H. ST-T } \\
\text { wave changes II, III, } \\
\text { V5, V6 }\end{array}$ & $\begin{array}{l}\text { Prolapse posterior cusp mitral } \\
\text { valve. Moderate mitral in- } \\
\text { competence }\end{array}$ \\
\hline 2 & $\mathbf{F}$ & 55 & Anterior chest pain & - & + & Mid and late clicks. Late & Normal & 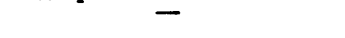 \\
\hline 3 & $\mathbf{F}$ & 57 & Nil & - & + & Mid-late click. Late sys. & Partial right bundle- & \\
\hline 4 & $\mathbf{F}$ & 32 & $\begin{array}{l}15 \text { years' anterior chest } \\
\text { pain }\end{array}$ & 一 & 2 Children normal & $\begin{array}{l}\text { Mid and late clicks. Late } \\
\text { systolic murmur }\end{array}$ & $\begin{array}{l}\text { L.V.H. Flat T waves } \\
\text { with inversion II, III, } \\
\text { AVF, V4-V6. V.E.S. }\end{array}$ & $\begin{array}{l}\text { Prolapse posterior cusp mitral } \\
\text { valve. Mild mitral incom: } \\
\text { petence }\end{array}$ \\
\hline 5 & $\mathbf{F}$ & 40 & Nil & - & Brother $\stackrel{+}{\text { normal }}$ & $\begin{array}{l}\text { Late click. Soft, late sys- } \\
\text { tolic murmur }\end{array}$ & Normal & - \\
\hline 6 & $\mathbf{F}$ & 36 & $\begin{array}{l}\text { Severe anterior chest } \\
\text { pain }\end{array}$ & - & $\begin{array}{l}3 \text { Children and half- } \\
\text { sister normal }\end{array}$ & $\begin{array}{l}\text { Mid-late click. No sys- } \\
\text { tolic murmur }\end{array}$ & Normal & $\begin{array}{l}\text { Prolapse posterior cusp mitral } \\
\text { valve. No mitral incom- } \\
\text { petence. Normal coronary } \\
\text { arteries }\end{array}$ \\
\hline 7 & $\mathbf{F}$ & 53 & $\begin{array}{l}\text { Anterior chest pain. } \\
\text { Dyspnoea }\end{array}$ & - & - & $\begin{array}{l}\text { Mid and late clicks. Late } \\
\text { systolic murmur }\end{array}$ & Normal & $\begin{array}{l}\text { Prolapse posterior cusp mitral } \\
\text { valve. Mitral incompetence. } \\
\text { Normal coronary arteries }\end{array}$ \\
\hline 8 & $\mathbf{F}$ & 44 & $\begin{array}{l}\text { Anterior chest pain. } \\
\text { Dyspnoea }\end{array}$ & $\begin{array}{l}\text { Murmur aged } \\
10 \text { years }\end{array}$ & - & $\begin{array}{l}\text { Mid click. Ejection } \\
\text { murmur }\end{array}$ & V.E.S. Flat ST V4-V6. & $\begin{array}{l}\text { Prolapse posterior cusp mitral } \\
\text { valve. Mild mitral incom- } \\
\text { petence }\end{array}$ \\
\hline 9 & $\mathbf{M}$ & 28 & Dyspnoea on exertion & - & - & $\begin{array}{l}\text { Mid click. Late systolic } \\
\text { murmur }\end{array}$ & L.V.H. & $\begin{array}{l}\text { Prolapse posterior cusp mitral } \\
\text { valve. Moderate mitral in- } \\
\text { competence }\end{array}$ \\
\hline 10 & $\mathbf{F}$ & 59 & $\begin{array}{l}\text { Chest pain. Thyro- } \\
\text { toxicosis }\end{array}$ & - & - & $\begin{array}{l}\text { Late click. Early systolic } \\
\text { murmur }\end{array}$ & $\begin{array}{l}\text { L.V.H. Tall } T \text { waves } \\
\text { anterior chest leads }\end{array}$ & - \\
\hline 11 & $\mathbf{F}$ & 48 & & ? Infarct & - & $\begin{array}{l}\text { Late click. Late systolic } \\
\text { murmur }\end{array}$ & ST depression II and & - \\
\hline 12 & $\mathbf{F}$ & 67 & Angina pectoris & - & - & $\begin{array}{l}\text { Late click. Late systolic } \\
\text { murmur }\end{array}$ & ST depression II and & - \\
\hline 13 & $\mathbf{M}$ & 40 & $\mathrm{Nil}$ & - & 4 Brothers & Multiple clicks & $\begin{array}{l}\text { Flat } T \text { waves II, III, } \\
\text { AVF, V5, V6 }\end{array}$ & - \\
\hline
\end{tabular}

patients as the opportunity arose. Three sisters in one family (Cases 1-3) had similar auscultatory findings (Fig. 1): haemodynamic studies were carried out in one of them. In the second family two sisters (Cases 4 and 5) had similar auscultatory findings (Fig. 2), though their brother and the children of one of them were normal. The half-sister and three children of another patient (Case 6) were examined and found to be normal.

The abnormal findings in all cases were limited to auscultation. In no case was there any clinical evidence of ventricular hypertrophy or cardiac failure, and all had normal blood pressure. The first and second sounds were normal, but in all cases clicks were present. In seven cases the click was latesystolic, in two cases mid-systolic, and in four cases multiple.

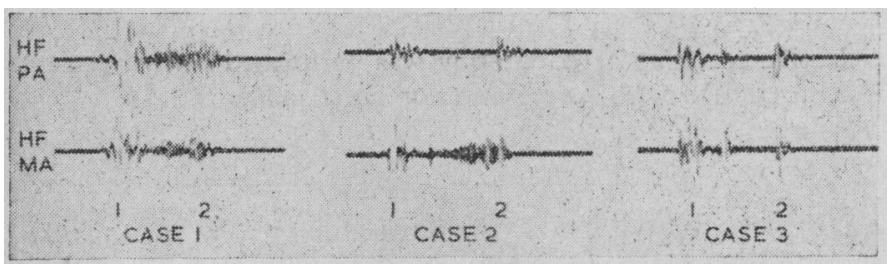

Fig. 1.-Phonocardiograms of three sisters showing first and second heart sounds ( 1 and 2 ), the mid-systolic click, and the late systolic murmur. ( $\mathrm{PA}=$ pulmonary area ; $\mathrm{MA}=$ mitral area ; $\mathrm{HF}=$ high frequency.)

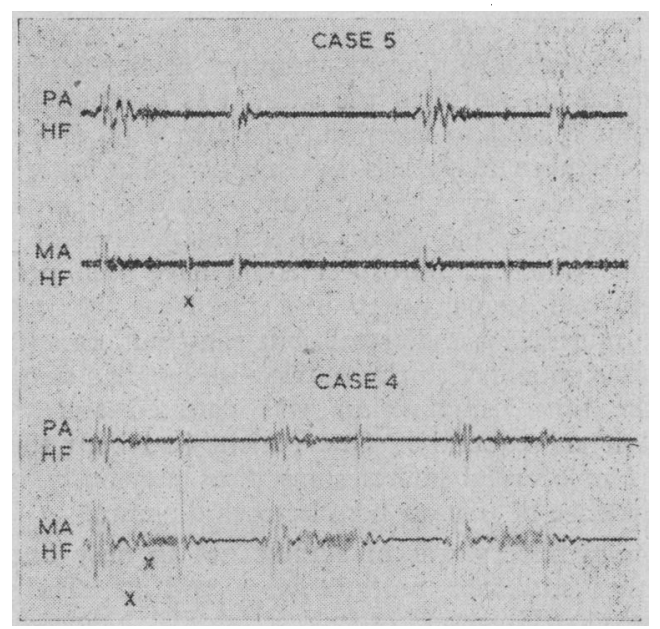

FIG. 2.-Phonocardiograms of two sisters showing the systolic click and late systolic murmur.
In nine cases a late systolic murmur (Fig. 3) was heard, loudest at the apex, but in two cases isolated clicks were the only abnormal findings. In one case the murmur was very loud and "musical," varying with posture (Fig. 4). The remaining two patients had systolic murmurs.

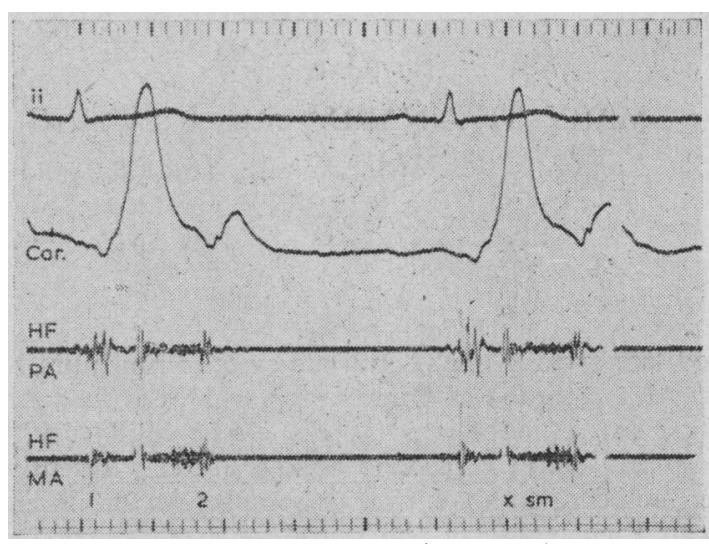

FIG. 3.-Case 9. Phonocardiogram showing the characteristic mid-systolic click (X) and late systolic murmur (SM). (ii = electrocardiogram lead II, Car. = carotid tracing, $\mathrm{PA}=$ pulmonary area, $\mathrm{MA}=$ mitral area, $\mathrm{HF}=$ high frequency.)

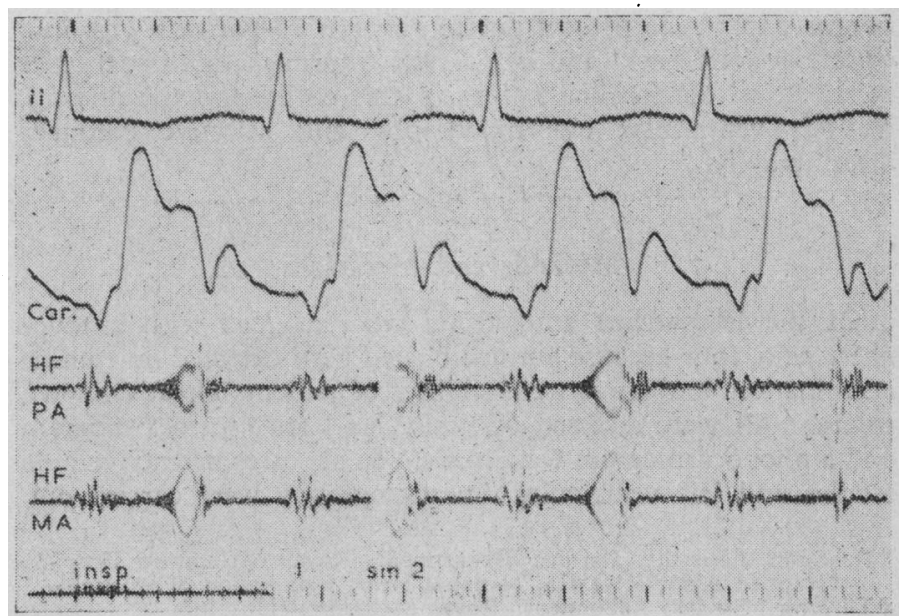

FIG. 4.-Case 4. Phonocardiogram showing loud "musical" late systolic murmur. 
The electrocardiograms did not show any constant abnormality. In four patients they were normal. In two of these severe chest pain was the presenting symptom, but no abnormalities appeared during pain or after exercise on a treadmill. In another four left ventricular hypertrophy could be diagnosed ( $S$ in $\mathrm{V} 1+\mathrm{R}$ in $\mathrm{V} 5>35 \mathrm{~mm}$.)-in three in association with ST-T wave abnormalities. Four patients had ST or $T$ wave abnormalities alone (see Table I) (in leads II, III, AVF, and the lateral chest leads) and one patient had a partial right bundle-branch block. Ventricular extrasystoles were present in three cases (Figs. 5 and 6 ). The chest $x$-ray picture in all cases was regarded as being within normal limits, there being

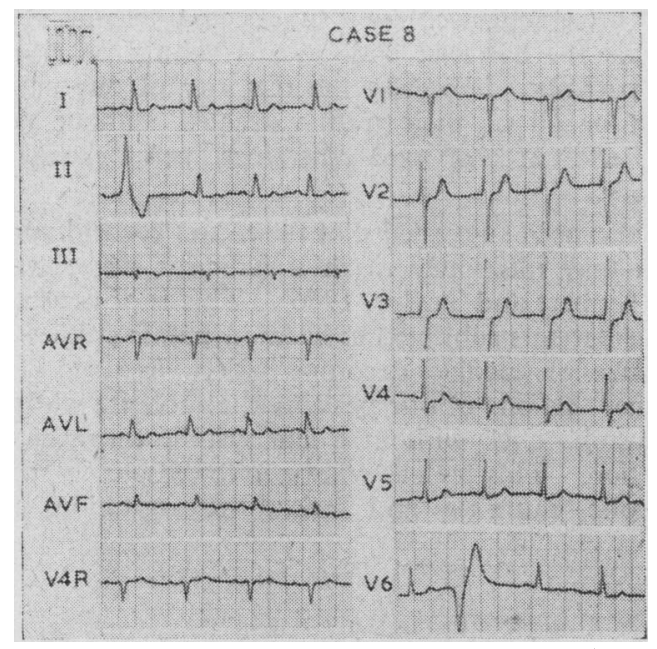

FIG. 5.-Case 8. Electrocardiogram showing ventricular extrasystoles and ST-T wave changes.

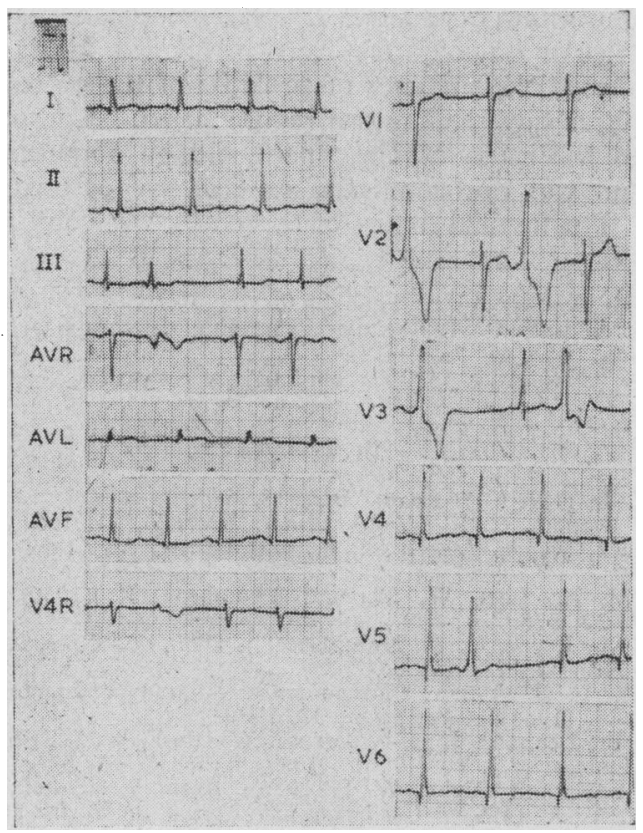

FIG 6.-Case 4. Electrocardiogram showing ventricular extrasystoles and widespread ST-T wave abnormalities

TABLE II.-Haemodynamic Findings in Six Patients

\begin{tabular}{|c|c|c|c|c|c|c|c|}
\hline \multirow[t]{2}{*}{$\begin{array}{l}\text { Case } \\
\text { No. }\end{array}$} & $\begin{array}{c}\text { Right } \\
\text { Atrium }\end{array}$ & $\begin{array}{l}\text { Right } \\
\text { Ven- } \\
\text { tricle }\end{array}$ & $\begin{array}{c}\text { Pulmonary } \\
\text { Artery }\end{array}$ & $\begin{array}{c}\text { Mean } \\
\text { Pulmonary } \\
\text { Artery } \\
\text { Wedge }\end{array}$ & $\begin{array}{l}\text { Left } \\
\text { Ven- } \\
\text { tricle }\end{array}$ & Aorta & \multirow[t]{2}{*}{$\begin{array}{l}\text { Cardiac } \\
\text { Output } \\
\text { (1./min.) }\end{array}$} \\
\hline & \multicolumn{6}{|c|}{ All Pressures in mm. $\mathrm{Hg}$} & \\
\hline $\begin{array}{l}1 \\
4 \\
6 \\
7 \\
8 \\
9\end{array}$ & $\begin{aligned}-3 & \text { mean } \\
2 & \Rightarrow \\
0 & \prime \\
2 & \prime \\
-2 & \Rightarrow \\
0 & \Rightarrow\end{aligned}$ & $\begin{array}{l}20 /-2 \\
17 /-2 \\
17 / 0 \\
25 / 0 \\
20 /-3 \\
25 / 0\end{array}$ & $\begin{array}{llr}18 / 3 & \text { mean } & 7 \\
17 / 7 & \text { " } & 13 \\
18 / 5 & \text { " } \\
25 / 8 & 11 \\
20 / 3 & 13 \\
23 / 4 & 8 & 10\end{array}$ & $\begin{array}{l}0 \\
6 \\
5 \\
3 \\
5 \\
3\end{array}$ & $\begin{array}{l}110 / 3 \\
125 /-1 \\
105 / 4 \\
125 / 0 \\
100 /-3 \\
155 / 5\end{array}$ & \begin{tabular}{|l|}
$110 / 60$ \\
$115 / 70$ \\
$105 / 70$ \\
$125 / 60$ \\
$100 / 55$ \\
$125 / 70$
\end{tabular} & $\begin{array}{l}3 \cdot 2 \\
5 \cdot 8 \\
5 \cdot 6 \\
5 \cdot 3 \\
6 \cdot 2 \\
5 \cdot 7\end{array}$ \\
\hline
\end{tabular}

no cardiomegaly, left atrial enlargement, or intracardiac calcification. Haemodynamic studies were carried out in six patients (Table II), and in all cases were normal. In particular there was no elevation of the left atrial pressure (pulmonary artery wedge) or of the left ventricular end-diastolic pressure, indicating that the mitral regurgitation was mild.

Left ventricular cineangiography was carried out in six patients. The mitral valve was studied in all six in the right anterior oblique position and in four of these in the left anterior oblique position with the head of the table raised 15 degrees. Prolapse of the posterior leaflet of the mitral valve into the left atrium during ventricular systole was demonstrated in all cases (Figs. 7, 8, and 9). Late mitral regurgitation was present in the five patients with a late systolic murmur, but was absent in the patient with an isolated click.

In addition, selective coronary arteriography was performed in the two patients with severe chest pain, and in both cases the coronary arteries showed no abnormality. The coronary arteries showed no evidence of atheroma and all major branches could be seen clearly, including the branches along the diaphrag-
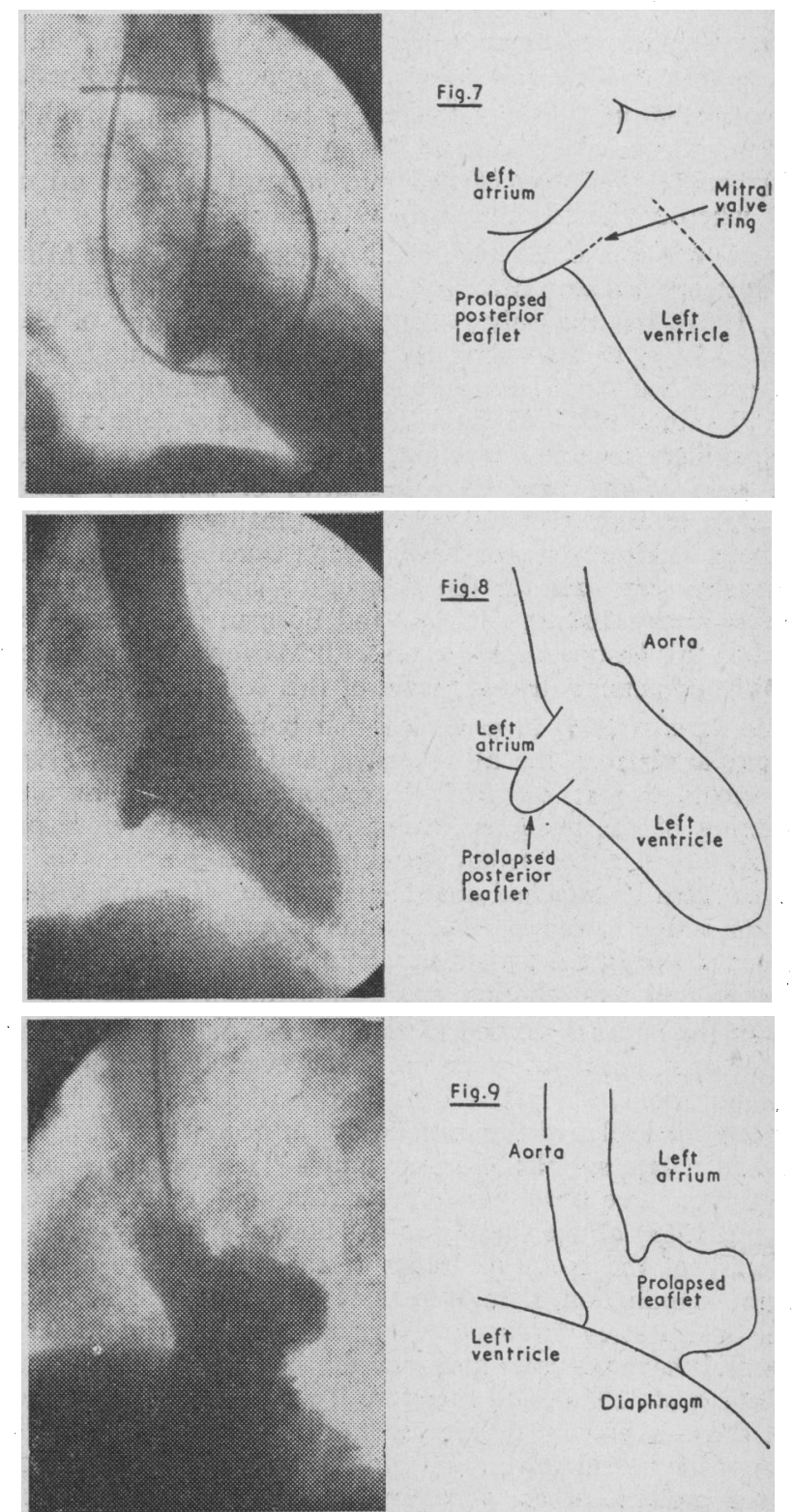

FIGS. 7 and 8.- Left ventricular angiograms (and line drawings) in the right anterior oblique position showing prolapse of the posterior leaflet of the mitral valve into the left atrium and mitral regurgitation. FIG. 9.- Left ventricular angiogram (and line drawing) in the left anterior oblique position, with the head of the table elevated 15 degrees, showing prolapse of the posterior leaflet of the mitral valve into the left atrium. 
matic aspect of the heart which supply the papillary muscles (James, 1965). There was no evidence of phasic narrowing of the circumflex artery during ventricular systole.

\section{Discussion}

We consider that the finding of a mid or late systolic click and a late systolic murmur in the mitral area is suggestive, if not diagnostic, of prolapse of the posterior leaflet of the mitral valve. Few patients have been investigated, but all reports to date have confirmed the presence of this abnormality in those patients with the characteristic auscultatory findings. Barlow and Bosman (1966) investigated only those patients with an abnormal electrocardiogram, but we have shown, as have other authors, that this is not necessary for diagnosis.

The cause of the chest pain and the abnormal electrocardiogram, where present, remains obscure. Barlow and Bosman (1966) have suggested that the prolapsing posterior leaflet causes compression of the circumflex branch of the left coronary artery, and that ischaemia of the posterior myocardium results. Selective coronary arteriography was performed in two of our patients because of the presence of severe chest pain, but in neither case was there any evidence to support this hypothesis.

The familial incidence of this entity has been noted by other authors, and we have confirmed this in two families. Extensive family studies were not carried out, and we therefore do not know whether the lesion is usually familial.

There was no other obvious aetiological factor. Mitral incompetence has been described after chest injury (McLaughlin et al., 1964), but the only patient with a past history of chest injury had two siblings similarly affected. Rheumatic fever or pericarditis could not be diagnosed, even retrospectively, in any case. Phillips et al. (1963) have described a late systolic murmur after papillary muscle infarction, and it was thought that the chest pain might have been indicative of papillary muscle ischaemia, leading to a functional abnormality of the chordae tendineae. However, we have demonstrated that the valve abnormality can exist in the absence of either chest pain or coronary artery disease. Barlow and Bosman (1966) have also described this lesion in association with Marfan's syndrome, but none of our patients had stigmata of this condition.

Leon et al. (1966) have shown that both the click and the murmur arise from the mitral valve, and Criley et al. (1966) have recorded that the click corresponds with the maximal ballooning of the posterior leaflet. The click therefore presumably arises either from stretching of the posterior leaflet itself or from its attached chordae tendineae. The late systolic murmur is due to mitral regurgitation occurring late in systole, and was absent in the patient in whom prolapse of the posterior leaflet without regurgitation was demonstrated.

In all the patients studied to date no material has been available for anatomical investigation. However, Barlow (personal communication, 1966) has described marked enlargement of the posterior leaflet of the mitral valve at necropsy in a patient who had a late systolic murmur and a "non-ejection" click. In addition there have been reports (Osmundson et al., 1961 ; Hudson, 1965) of the finding of a "hooded " or "parachute" deformity of the posterior leaflet of the mitral valve at postmortem examination, though in these cases there was no record of the auscultatory findings. Normally the posterior leaflet of the mitral valve occupies only one-third of the total valve area (Chiechi et al., 1956), and therefore it would seem that in these cases there is an actual increase in the size of the posterior leaflet of the mitral valve. There is also support for the theory that the prolapse of the posterior leaflet of the mitral valve is due to an abnormality of the attached chordae tendinae. Four normal hearts were dissected in ordcr to study the anatomy of the chordae tendineae attached to the posterior leaflet of the mitral valve. When the chordae tendineae of the "third order" (Chiechi et al., 1956) were severed it was seen that prolapse of the posterior leaflet into the left atrium could occur, whereas when a major chorda tendinea was severed the valve became completely incompetent. We therefore believe that the anatomical abnormality in these patients will prove to be enlargement of the posterior leaflet of the mitral valve together with an abnormality of the chordae tendineae or papillary muscles.

It has been suggested by Linhart and Taylor (1966) that sprophylaxis for bacterial endocarditis should be administered to these patients. However, the majority of our patients had had most or all of their teeth extracted without developing bacterial endocarditis, and therefore prophylaxis may be unnecessary.

It has also been suggested that the mitral regurgitation in this condition may ultimately reach a sufficient degree to warrant surgery (Linhart and Taylor, 1966). This is of course possible, but in our patients subjected to haemodynamic studies there was no evidence of cardiac decompensation, even in those past middle age. In one of our patients the prolapse was associated with a systolic click without a late systolic murmur or mitral regurgitation. This patient will be followed closely to see if the late systolic murmur and mitral regurgitation eventually develop.

\section{Summary}

Thirteen patients with mid or late systolic clicks and late systolic murmurs were studied. Haemodynamic studies and left ventricular angiography were performed in six of these, and confirmed the presence of prolapse of the posterior leaflet of the mitral valve and mitral regurgitation. Coronary artery disease as the cause of chest pain and an abnormal electrocardiogram was not confirmed on selective coronary arteriography. The familial nature of this entity was confirmed.

We wish to thank the physicians of the Royal Melbourne Hospital who referred patients for study. The line drawings were done by Miss J. Miles.

\section{REFERENCES}

Barlow, J. B. (1965). Y. chron. Dis., 18, 665.

Barlow, Heart 7., 71, 166.

— Pocock, W. A., Marchand, P., and Denny, M. (1963). Ibid., 66, P43.

Chiechi, M. A., Lees, W. M., and Thompson, R. (1956). \%. thorac. Surg., 32, 378.

Criley, J. M., Lewis, K. B., Humphries, J. O'N., and Ross, R. S. (1966). Brit. Heart ₹., 28, 488.

Hudson, R. E. B.' (1965). Cardiovascular Pathology. London.

James, T. N. (1965). Circulation, 32, 1020.

Leon, D. F., Leonard, J. J., Kroetz, F. W., Page, W. L., Shaver, J. A., and Lancaster, J. F. (1966). Amer. Heart f., 72, 325.

Int J. W. and Taylor W. J. (1966). Amer. 7. Cardiol., 18, 164

McKusick, V. A. (1958). Cardiovascular Sound in Health and Disease. Baltimore.

McLaughlin, J. S., Cowley, R. A., Smith, G., and Matheson, N. A. (1964). '\%. thorac. cardiovasc. Surg., 48, 261.

Ongley, P. A. Sprague, H. B., Rappaport, M. B., and Nadas, A. S. (1960). Heart Sounds and Murmurs. New York.

Osmundson, P. J., Callahan, J. A., and Edwards, J. E. (1961). Circulation, 23, 42 .

Phillips, J. H., Burch, G. E., and De Pasquale, N. P. (1963). Ann. intern. Med., 59, 508.

Segal, B. L., and Likoff, W. (1964), Amer. Heart 7., 67, 757

Tavel, M. E., Campbell, R. W., and Zimmer, J. F. (1965). Amer. J. Cardiol., 15, 719.

Wells, B. (1957). Brit. Heart 7, 19, 129. 